\title{
Leaching of Heavy Metals in Soils Conditioned with Biosolids from Sewage Sludge
}

\author{
Thaís Campos ${ }^{1}$ (D), Guilherme Chaer ${ }^{2}$, Paulo dos Santos Leles ${ }^{1}$, Marcelo Silva ${ }^{1}$, \\ Felipe Santos ${ }^{1}$
}

\begin{abstract}
${ }^{1}$ Universidade Federal Rural do Rio de Janeiro, Seropédica/RJ, Brasil
${ }^{2}$ Empresa Brasileira de Pesquisa Agropecuária, Seropédica/RJ, Brasil
\end{abstract}

\begin{abstract}
A promising use of biosolids is as organic fertilizer in agricultural and forestry activities. However, its composition might contain several pollutants, especially heavy metals, which may result in an increase in the concentrations of these elements in the soil and the risk of groundwater contamination. This study aimed to determine the leaching levels of ions in a Ferralsol (clayey texture) and in a Planosol (sandy texture). The experiment was conducted in a greenhouse at Embrapa Agrobiologia, Seropédica, Rio de Janeiro state. Soils were packed in PVC columns and received $2 \mathrm{~L}$ /column of biosolids. The concentrations of heavy metals present in the biosolids composition were below the limits established by the legislation (CONAMA 375). In addition, the performed simulations showed the absence of contamination risk of soil or groundwater and surface water, according to the limits allowed by CONAMA 375. However, it should be emphasized the potential of nitrate leaching.
\end{abstract}

Keywords: contamination risk, chemical elements percolation, test with columns, risk analysis. 


\section{INTRODUCTION}

The sewage collected from residences and treated in sewage treatment station generates a by-product called sewage sludge. For its final disposal, sewage sludge must be treated aiming at reducing biodegradable solids and odors, stabilizing organic matter, reducing sludge volume and the presence of vectors. After the sludge treatment steps, it is called biosolid.

The production of sewage sludge has grown in many countries due to increase of population and improvements in the sewage collection and treatment systems (Passuello et al., 2012). Therefore, the management of this product became an environmental problem. According to Paramashivam et al. (2017), biosolids disposal to landfill or through incineration is waste of a resource that is rich in organic matter and plant nutrients. Biosolids are significant sources of nitrogen $(\mathrm{N})$, phosphorus $(\mathrm{P})$, organic matter and other elements necessary for plant nutrition (Plachá et al., 2008). Hence this use is a more economical alternative to final disposal of biosolids, because it recycles the nutrients contained therein and collaborates with the increase of the organic matter content of the soil (Ricci et al., 2010).

Due to its constitution predominantly organic, when incorporated into the soil, biosolid provides improvement in the state of particles aggregation, causing a decrease in the density and increase of the macro porosity, which enables its greater aeration and water retention capacity (Prado \& Cunha, 2011).

However, the biosolids can present in its composition pollutants such as heavy metals, persistent organic compounds and pathogenic organisms to man, representing a potential health and environmental risk. Thus, a greater knowledge regarding the behavior of these elements present in the biosolids from sewage sludge is of great relevance in order to guide the application of this waste safely and with benefits associated to soil quality and crops production.

\section{AIMS}

The objective of this study was to obtain information about the security level of biosolids application in forest plantations in relation to the accumulation and the leaching of heavy metals, and the leaching of nutrients with the potential of water bodies eutrophication.

\section{MATERIAL AND METHODS}

\subsection{Place of study and experimental design}

The study was conducted in a greenhouse at Embrapa Agrobiologia, Seropédica, Rio de Janeiro state (RJ). The biosolids were originated from sewage treatment station of Ilha do Governador, RJ. The experiment followed $2 \times 1$ factorial with three replications, in a completely randomized design. The factors studied were soil texture (sandy and clay soils) and dose of biosolid. In addition, the absolute control (without biosolid application) was utilized for both levels of soil texture, totalizing 12 columns.

The experimental units consisted of PVC columns of $0.1 \mathrm{~m}$ in diameter and $0.5 \mathrm{~m}$ in height (Figure 1). The volume of this connection was filled with gravel $\mathrm{n}^{\circ} 1$ in order to facilitate the drainage of the percolated liquid and to support the soil on the plastic mesh located between the soil and the gravel. The gravel used was previously rinsed in a hydrochloric acid solution (3\%) for removal of impurities.

The soil columns were filled with: a Ferralsol (Latossolo Amarelo distrófico, according to Brazilian Soil Classification System/BSCS) with clay texture, collected in the area of Cerâmica Vulcão company, located at Queimados, RJ; and a Planosol (Planossolo Háplico, according to BSCS) with sandy texture, collected in Embrapa Agrobiologia's experimental field, located at Seropédica, RJ. Both soils were sampled in layers from 0 to $0.25 \mathrm{~m}$ and 0.25 to $0.5 \mathrm{~m}$ depth.

The biosolid was mixed on the top layer ( 0 to $0.25 \mathrm{~m}$ ) of the column by simulating the application into a hole of planting of approximately $8 \mathrm{~L}$, which would be equivalent, for example, to a hole with approximate dimensions of $0.20 \mathrm{~m}$ diameter and $0.25 \mathrm{~m}$ height. Considering a forest planting with a density of 1250 plants/ha (for instance a planting spacing $4 \mathrm{~m} \times 2 \mathrm{~m}$ ) the quantity of biosolids applied in the columns would be equivalent to $10 \mathrm{~m}^{3} / \mathrm{ha}$.

After mounting, the columns were taken to the greenhouse and kept incubated for approximately 60 days before the beginning of the leaching period. 

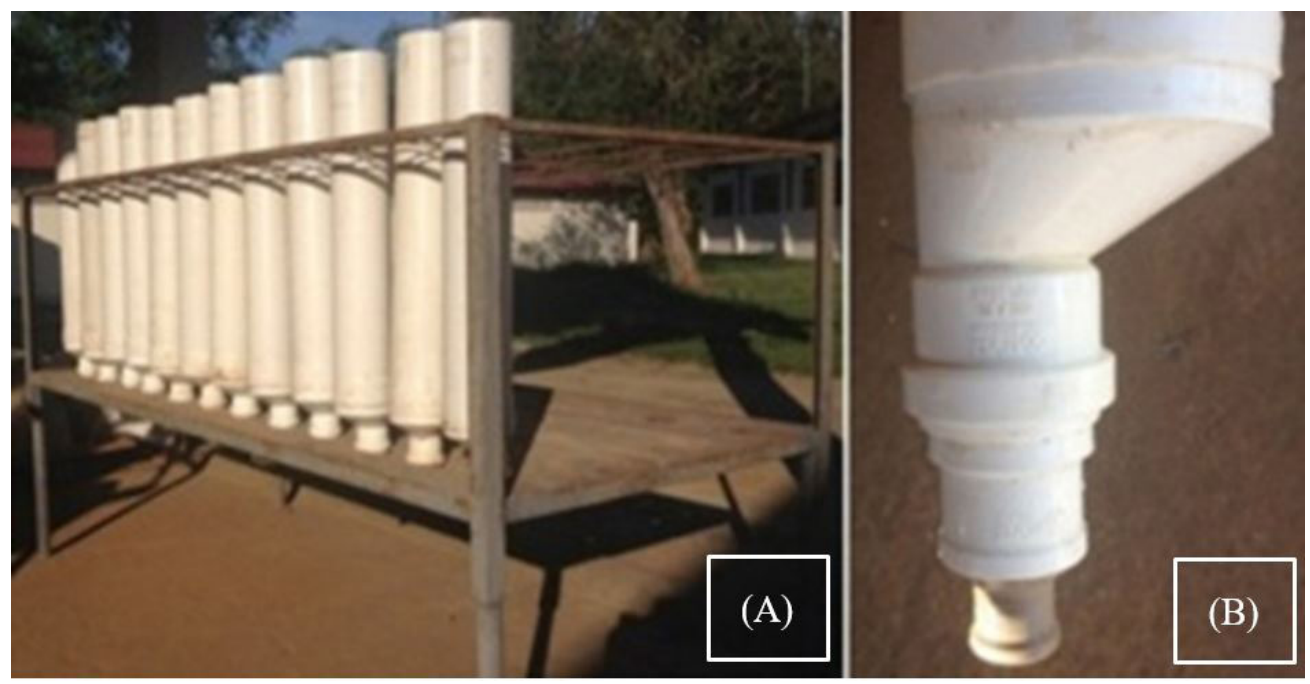

Figure 1. (A) PVC columns used as experimental units supported in structure mounted to leave them in the vertical position. (B) Detail of the adaptation attached to the base of the soil columns for collection of percolated liquid.

\subsection{Simulation of rain and the collection of columns leachate}

Based on the volume of rain equivalent to the largest daily precipitation for the municipality of Seropédica during a period of 16 years, according to INMET, a blade of $140 \mathrm{~mm}$ of deionized water per saturated column was applied. Thus, fractions of $0.2 \mathrm{~L}$ (equivalent to $23.3 \mathrm{~mm}$ ) were applied at intervals of 2 hours for 12 hours, which resulted in a total of $1.2 \mathrm{~L}$. After 24 hours of the first application of water, $0.2 \mathrm{~L}$ of water were applied again and so forth, every 24 hours for 45 days. After each addition of water to the columns, the leachate was collected in container flasks of $0.25 \mathrm{~L}$ and stored in tubes type Falcon of $0.05 \mathrm{~L}$ at $20^{\circ} \mathrm{C}$ until analysis.

\subsection{Chemical analysis of the leachate}

The leachate samples were analyzed regarding the anion's contents (nitrate and phosphate), metals (silver, arsenic, barium, boron, cadmium, cobalt, chromium, copper, iron, manganese, nickel, lead, selenium and zinc), in addition to aluminum, antimony and vanadium.

The analyses were performed by the Laboratory of Quality Control Management of Water - GCQ of Nova CEDAE. The concentrations of anions were determined by ion chromatography and the concentrations of metals by ICP/OES method.

\subsection{Maximum load of biosolids application}

The CONAMA Resolution $n^{\circ} 375$ establishes the theoretical cumulative load permitted of inorganic substances by application of sewage sludge or derivative product. To obtain the maximum load of biosolids specific to each metal, the Equation (1) below was used:

$\operatorname{CMBi}(\mathrm{Mg} / \mathrm{ha})=\mathrm{CATi} \times 10^{3} / \mathrm{CBi}$

Where: $\mathrm{CMB} i$ is the maximum load of biosolids to the metal $i$ in $\mathrm{Mg} / \mathrm{ha}$; CAT $i$ is the theoretical accumulated charge to the metal $i$ defined in the legislation; and $\mathrm{CB} i$ is the concentration of the metal $i$ in the biosolids used in the study.

\subsection{Analysis of the soil contamination risk}

The contamination risk was evaluated taking as reference the research value for metals allowed in agricultural soil, according to CONAMA (2009) Resolution $n^{\circ} 420 / 2009$. It was considered the concentration of metals accumulated in the soil $(\mathrm{mg} / \mathrm{kg})$ as being the difference between the added quantity through biosolids and the total leached by application of $1.2 \mathrm{~m}$ of water blade, a higher precipitation for the municipality of Seropédica. The obtained value corresponded to the concentration of metal accumulated in the soil being expressed in concentration in the planting hole and per ha. The concentration of metal per ha was obtained by calculating the ratio 
between the total contents of metal accumulated in 1 ha ( $10 \mathrm{~m}^{3}$ of biosolids) and the mass of upper soil layers, i.e., $2 \times 10^{6} \mathrm{~kg}$ of soil ( 0 to $0.2 \mathrm{~m}$, apparent density of $1 \mathrm{~g} / \mathrm{dm}^{-3}$ ), according to the Equation (2) below:

$$
\operatorname{CMSi}(\mathrm{mg} / \mathrm{kg})=(Q B i-Q L i) / 2 \times 10^{6}
$$

Where: CMS $i$ is the concentration of metal $i$ expected in the soil in $\mathrm{mg} / \mathrm{kg}$; QBi is the quantity of metal $i$ in $10 \mathrm{~m}^{3}$ of biosolids; QLi is the quantity of metal $i$ leached in 1 ha in $\mathrm{mg} / \mathrm{ha}$; and $2 \times 10^{6}$ is the mass of upper soil layer in $1 \mathrm{ha}(\mathrm{kg} / \mathrm{ha})$. The risk assessment was then performed by comparing the CMSi of each metal with the respective limits established in the CONAMA Resolution no 420/2009.

\subsection{Analysis of the groundwater contamination risk}

The analysis of the groundwater contamination risk was based on the limits of metals in groundwater established in CONAMA Resolution n 420/2009. First, the total content of metals leached in columns that received the greatest load of biosolids $(2 \mathrm{~L})$ were converted to content leached in $1 \mathrm{ha}(\mathrm{mg} / \mathrm{ha})$. Thus, it was considered that the application of $8 \mathrm{~L}$ per hole of $0.2 \mathrm{~m}$ diameter and $0.25 \mathrm{~m}$ depth $\left(0.0079 \mathrm{~m}^{2}\right.$ projection area) and planting density of 1250 plants/ha and is therefore equivalent to the application of a load of $10 \mathrm{~m}^{3}$ of biosolids per ha concentrated in an area of total projection of $39.3 \mathrm{~m}^{2} /$ ha (1250 holes). The amount leached was then obtained by the Equation (3) below:

$$
Q L i(m g / h a)=A P C \times Q C \times Q L C i / A C o l
$$

Where: QL $i$ is the amount leached of the metal $i$ per ha; APC is the projection area of a hole of $0.2 \mathrm{~m}$ diameter $\left(\mathrm{m}^{2}\right)$; QC is the number of holes in $1 \mathrm{ha}$; QLC $i$ is the total amount of metal $i$ leached in column; and ACol is the projection area of the leaching column $\left(\mathrm{m}^{2}\right)$.

Then it was agreed that $80 \%$ of leachable metal load in a water depth of $1.2 \mathrm{~m}$ (value equivalent to 1 year of precipitation in the study site) is leached in a percolated blade of water of $140 \mathrm{~mm}$, equivalent to a volume of 1.4 million $\mathrm{L} / \mathrm{ha}$.

Finally, the concentration of each metal in the percolated volume was obtained by dividing the contents of leached metal in 1 ha by the volume of percolated water, according to the Equation (4) below:

$C M A S i(\mu g / L)=(Q L i \times 1000) / V A P$
Where: CMAS $i$ is the concentration of the metal $i$ expected in underground water $(\mu \mathrm{g} / \mathrm{L})$; QL $i$ is the quantity of metal $i$ leached in $1 \mathrm{ha}(\mathrm{mg} / \mathrm{ha})$; and VAP is the volume of percolated water (L/ha), established in this study (1.4 million L/ha). The risk assessment was then performed by comparing the CMAS of each metal with the respective limits established in the CONAMA Resolution no 420/2009.

It should be pointed out that the estimate of CMAS ignores the previous presence of underground water. In other words, disregards a possible dilution of the percolated solution.

\subsection{Analysis of the eutrophication of superficial waters}

The eutrophication of superficial waters was evaluated based on the total phosphorus values indicated in the classification table of trophic state of rivers and reservoirs, according to the Modified Carlson's Trophic State Index (Cetesb, 2007). The performed simulation had the same assumptions of the risk assessment of groundwater contamination: (1) application of $10 \mathrm{~m}^{3} /$ ha of biosolids in 1250 holes of $0.2 \mathrm{~m}$ in diameter by $0.25 \mathrm{~m}$ deep; (2) leaching of $80 \%$ of the load of the ion $\mathrm{PO}_{4}{ }^{3-}$ in a water blade of $140 \mathrm{~mm}$ or 1.4 million $\mathrm{L} / \mathrm{ha}$. The phosphate concentration in percolated volume was obtained according to the Equation (5) below:

$C P A S(\mu g / L)=(Q P \times 1000) / V A P$

Where: CPAS is the phosphate concentration expected in underground water $(\mu \mathrm{g} / \mathrm{L})$; QP is the quantity of leached phosphate in 1 ha $(\mathrm{mg} / \mathrm{ha})$; and VAP is the volume of percolated water ( $\mathrm{L} / \mathrm{ha})$, established in this study, as equivalent to one blade of water of $140 \mathrm{~mm}$ or 1.4 million L/ha. The risk evaluation was then performed comparing the calculated CPAS with the classification table of trophic state of rivers and reservoirs according to the Modified Carlson's Trophic State Index (Cetesb, 2007).

\section{RESULTS AND DISCUSSION}

\subsection{Quality of biosolids and soil contamination risk}

It was found that all results for heavy metals are below the limits laid down in the CONAMA (2006) Resolution $n^{\circ} 375 / 2006$. Thus, for these requirements 
the biosolids produced in the ETE Ilha do Governador meets the requirements for use in agriculture. The levels of heavy metals present are very inferior compared to the restrictive for critical levels for its application in the soil (Table 1).

According to Gonçalves et al. (2012), studies related with successive applications of biosolids become necessary, since this practice can result in an increase in the levels of heavy metals in the soil. Consequently, it may introduce these elements in the food chain, causing contamination to animals, humans and the environment. Depending on the environmental conditions and the application rate in the soil, these elements can be leached in the soil profile, consequently contaminating groundwaters (Oliveira et al., 2010).

Therefore, an estimate was carried out of the maximum load of biosolids that could be applied in the soil before it reaches the limits of metals predicted in the legislation. Considering the accumulated maximum load permitted in CONAMA Resolution $375 / 2006 \mathrm{in} \mathrm{kg} / \mathrm{ha}$, a maximum total load of biosolids of $732 \mathrm{Mg} / \mathrm{ha}$ could be applied, necessary to raise the content of the element arsenic in soil to its allowed limit (Table 1). However, due to requiring a smaller amount of biosolids to achieve the critical limit ( $71 \mathrm{Mg} / \mathrm{ha})$, mercury would be the pollutant of reference for defining the application limit.
Using the same reasoning, it can be concluded that it would be necessary to apply approximately $700 \mathrm{Mg} / \mathrm{ha}$ of biosolids produced in ETE/IG for reaching the limit of lead (41 kg/ha), the most restrictive element in the soil, according to the simulation presented (Table 1). Thus, the environmental risk of using biosolids is low, considering the minimum quality requirements regarding the metals determined in the legislation. In addition, it is understood that biosolids with the same characteristics of that used in this study serve not only as a substrate for the production of forest seedlings (Caldeira et al., 2012; Cabreira et al., 2017; Abreu et al., 2017) but for restoration of degraded areas (Campos \& Alves, 2008; Sampaio et al., 2012; Nobrega et al., 2017).

A simulation of the risk of metals accumulation in the soil was also performed having as reference the CONAMA Resolution $n^{\circ} 420 / 2009$, which establishes the limits of metals in the soil above which there are direct or indirect risks to human health. The results presented in Table 2 simulate the concentration of metal accumulated in the planting hole by the application of $8 \mathrm{~L}$ of biosolids (obtained by subtracting the concentration of each metal contained in the biosolids of ETE/IG, from the total leached per column of each metal in the treatment with $8 \mathrm{~L}$ of biosolids) and the metal concentration in the upper layer soil, in case $10 \mathrm{~m}^{3} / \mathrm{ha}$

Table 1. Contents of heavy metals in biosolids, theoretical accumulated load of metal per hectare and theoretical maximum load of biosolids per hectare as defined by CONAMA Resolution $n^{\circ}$ 375/06 and the biosolids produced in ETE Ilha do Governador (ETE/IG).

\begin{tabular}{|c|c|c|c|c|c|c|}
\hline \multirow[t]{2}{*}{ Metal } & \multicolumn{2}{|c|}{$\begin{array}{l}\text { Metal content in biosolids } \\
\qquad(\mathrm{mg} / \mathrm{kg})\end{array}$} & \multicolumn{2}{|c|}{$\begin{array}{c}\text { Theoretical accumulated load } \\
\text { of metal by application of } \\
\text { sewage sludge (kg/ha) }\end{array}$} & \multicolumn{2}{|c|}{$\begin{array}{c}\text { The theoretical maximum load } \\
\text { of biosolids to reach critical } \\
\text { level (Mg/ha) }\end{array}$} \\
\hline & $\begin{array}{c}\text { CONAMA } \\
375 / 06\end{array}$ & $\begin{array}{l}\text { Biosolids } \\
\text { ETE-IG }\end{array}$ & $\begin{array}{l}\text { CONAMA } \\
375 / 06\end{array}$ & $\begin{array}{c}\text { Biosolids ETE- } \\
\text { IG }^{*}\end{array}$ & $\begin{array}{l}\text { CONAMA } \\
375 / 06^{* *}\end{array}$ & $\begin{array}{l}\text { Biosolids } \\
\text { ETE-IG }\end{array}$ \\
\hline As & 41 & $<1$ & 30 & 0.007 & 732 & 30,000 \\
\hline $\mathrm{Ba}$ & 1,300 & 137 & 265 & 0.959 & 204 & 1,934 \\
\hline $\mathrm{Cd}$ & 39 & 1.4 & 4 & 0.01 & 103 & 2,857 \\
\hline $\mathrm{Pb}$ & 300 & 58.4 & 41 & 0.409 & 137 & 702 \\
\hline $\mathrm{Cu}$ & 1,500 & 162 & 137 & 1.134 & 91 & 846 \\
\hline $\mathrm{Cr}$ & 1,000 & 21.9 & 154 & 0.153 & 154 & 7,032 \\
\hline $\mathrm{Hg}$ & 17 & $<1$ & 1.2 & 0.007 & 71 & 1,200 \\
\hline Mo & 50 & 1.6 & 13 & 0.011 & 260 & 8,125 \\
\hline $\mathrm{Ni}$ & 420 & 12.7 & 74 & 0.089 & 176 & 5,827 \\
\hline $\mathrm{Se}$ & 100 & $<1$ & 13 & 0.007 & 130 & 13,000 \\
\hline $\mathrm{Zn}$ & 2,800 & 531 & 445 & 3.717 & 159 & 838 \\
\hline
\end{tabular}

${ }^{*}$ Load accumulated by the theoretical application of $10 \mathrm{~m}^{3} / \mathrm{ha}(7 \mathrm{Mg} / \mathrm{ha})$ of biosolids. ${ }^{*}$ Estimate based on the theoretical cumulative load of metals by the application of sludge as defined in CONAMA Resolution $n^{\circ} 375 / 06$. 
Table 2. Value of research for metals in agricultural soils established by CONAMA Resolution n n $^{\circ} 20 / 2009$, concentration of metal accumulated in the planting hole after application of $8 \mathrm{~L}$ of biosolids, and concentration of metal accumulated in the soil considering the application of $10 \mathrm{~m}^{3} /$ ha of biosolids of ETE IG in total area or incorporated in the upper layer soil (0 to $0.2 \mathrm{~m}$ ).

\begin{tabular}{|c|c|c|c|c|c|c|c|c|}
\hline \multirow[t]{2}{*}{ Metal } & \multirow[t]{2}{*}{$\begin{array}{l}{ }^{* *} \text { VP for } \\
\text { metals in the } \\
\text { soil ( } \mathrm{mg} / \mathrm{kg})\end{array}$} & \multirow[t]{2}{*}{$\begin{array}{c}{ }^{\star} \mathrm{VI} \text { for } \\
\text { metals in } \\
\text { agricultural } \\
\text { soils (mg/kg) }\end{array}$} & \multicolumn{2}{|c|}{$\begin{array}{c}\text { Concentration of } \\
\text { metal accumulated } \\
\text { in the planting hole } \\
(\mathrm{mg} / \mathrm{kg})\end{array}$} & \multicolumn{2}{|c|}{$\begin{array}{l}\text { Accumulated metal } \\
\text { concentration in the } \\
\text { soil to } 10 \mathrm{~m}^{3} / \mathrm{ha} \text { of } \\
\text { biosolids }(\mathrm{mg} / \mathrm{kg})\end{array}$} & \multicolumn{2}{|c|}{$\begin{array}{l}\text { Percentage of the total } \\
\text { leaching of metal } \\
\text { contained in the } \\
\text { biosolids }\end{array}$} \\
\hline & & & Planosol & Ferralsol & Planosol & Ferralsol & Planosol & Ferralsol \\
\hline $\mathrm{Al}$ & - & - & 9,622 & 9,619 & 33 & 33 & $0 \%$ & $0 \%$ \\
\hline $\mathrm{Sb}$ & 2 & 5 & - & - & - & - & - & - \\
\hline As & 15 & 35 & 1 & 1 & 0.004 & 0.004 & $0 \%$ & $0 \%$ \\
\hline $\mathrm{Ba}$ & 150 & 300 & 134 & 135 & 0.47 & 0.47 & $1.30 \%$ & $0.60 \%$ \\
\hline B & - & - & 0.59 & 0.54 & 0.005 & 0.005 & $58.10 \%$ & $59.30 \%$ \\
\hline $\mathrm{Cd}$ & 1.3 & 3 & 1.39 & 1.39 & 0.005 & 0.005 & $0 \%$ & $0.30 \%$ \\
\hline $\mathrm{Pb}$ & 72 & 180 & 58 & 58 & 0.2 & 0.2 & $0 \%$ & $0 \%$ \\
\hline Co & 25 & 35 & - & - & - & - & - & - \\
\hline $\mathrm{Cu}$ & 60 & 200 & 161 & 161 & 0.57 & 0.56 & $0.10 \%$ & $0 \%$ \\
\hline $\mathrm{Cr}$ & 75 & 150 & 21 & 21 & 0.08 & 0.08 & $0 \%$ & $0 \%$ \\
\hline $\mathrm{Fe}$ & - & - & 19,252 & 19,249 & 67 & 67 & $0 \%$ & $0 \%$ \\
\hline $\mathrm{Mn}$ & - & - & 254 & 301 & 0.96 & 1.08 & $15.80 \%$ & $5.60 \%$ \\
\hline $\mathrm{Hg}$ & 0.5 & 12 & - & - & - & - & $0 \%$ & $0 \%$ \\
\hline Mo & 30 & 50 & - & - & - & - & $0 \%$ & $0 \%$ \\
\hline $\mathrm{Ni}$ & 30 & 70 & 12.6 & 12.5 & 0.04 & 0.04 & $0.10 \%$ & $1 \%$ \\
\hline $\mathrm{NO}_{3}^{-}$ & - & - & - & - & - & - & - & - \\
\hline $\mathrm{Ag}$ & 2 & 25 & - & - & - & - & - & - \\
\hline $\mathrm{Se}$ & 5 & - & 0.84 & 0.84 & 0.003 & 0.003 & $11.20 \%$ & $11.30 \%$ \\
\hline V & - & - & - & - & - & - & - & - \\
\hline $\mathrm{Zn}$ & 300 & 450 & 527 & 510 & 1.85 & 1.81 & $0.50 \%$ & $2.70 \%$ \\
\hline
\end{tabular}

${ }^{*}$ Research value according to CONAMA Resolution $n^{\circ} 420 / 2009$. ${ }^{* *}$ Prevention value according to CONAMA Resolution $n^{\circ} 420 / 2009$.

of biosolids is applied in total area and incorporated to $0.2 \mathrm{~m}$ depth (obtained by subtracting the total of each metal added by the biosolids of ETE IG/ha of the total leached per column considering application of $8 \mathrm{~L}$ or $10 \mathrm{~m}^{3} /$ ha, divided by the total quantity of soil contained in the upper layer soil, up to $0.2 \mathrm{~m}$ in $1 \mathrm{ha}$ ). All the elements presented values accumulated in the soil considerably below the limits required by the legislation, both for values of prevention and research. Thus, there is low potential of contamination by the accumulation of these elements in the soil.

\subsection{Environmental risk: underground water}

Considering the worst-case scenario, where there is no absorption by plants and nor the dilution of these elements in larger volumes of underground water, no heavy metal was detected in the leached material above the intervention values determined by CONAMA Resolution no 420/2009 (Table 3).
Studies on the movement of heavy metals in soils treated with biosolids suggest that the number of leachates may be substantially higher in soils with low levels of organic matter and subject to intense rains (Bertoncini \& Mattiazzo, 1999). The results obtained contradict those studies, since in general the leaching of metals was similar between the soils with sandy and clayey texture (Table 2). In fact, the only leached metals in relatively high percentages in relation to the added quantity via biosolids were manganese ( $\sim \%$ to $16 \%$ ), selenium ( 11\%) and boron ( 50\%).

In Brazil, studies have demonstrated that the metals $\mathrm{Cr}, \mathrm{Cu}, \mathrm{Ni}$ and $\mathrm{Pb}$ present in biosolids have low mobility, accumulating in the soil layer where the biosolids was incorporated, information that corroborates the data of this study. Whereas $\mathrm{Zn}$ and especially $\mathrm{Cd}$ are considered relatively movable, therefore, would have the greatest potential to contaminate soil and groundwaters (Merlino et al., 2010). The preferential retention of lead, 
Table 3. Limit of metals in groundwater established by CONAMA Resolution no 420/2009, quantity of leached metal estimated by application of $10 \mathrm{~m}^{3} /$ ha of biosolids, percentage of leached metal in relation to added quantity via biosolids and metal concentration estimated in groundwater after percolation of $140 \mathrm{~mm}$.

\begin{tabular}{|c|c|c|c|}
\hline \multirow[t]{2}{*}{ Metal } & \multirow{2}{*}{$\begin{array}{c}{ }^{*} \text { Intervention value } \\
\text { in underground water } \\
(\mu \mathrm{g} / \mathrm{L})\end{array}$} & \multicolumn{2}{|c|}{$\begin{array}{l}\text { Metal concentration in groundwater after } \\
\text { percolation of } 140 \mathrm{~mm}(\mu \mathrm{g} / \mathrm{L})\end{array}$} \\
\hline & & Planosol & Ferralsol \\
\hline $\mathrm{Al}$ & 3,500 & 0.33 & 13 \\
\hline $\mathrm{Sb}$ & 5 & 0.03 & 0.01 \\
\hline As & 10 & 0 & 0 \\
\hline $\mathrm{Ba}$ & 700 & 9.1 & 4 \\
\hline B & 500 & 9.3 & 9 \\
\hline $\mathrm{Cd}$ & 5 & 0.001 & 0.02 \\
\hline $\mathrm{Pb}$ & 10 & 0 & 0 \\
\hline Co & 70 & 1.4 & 0.2 \\
\hline $\mathrm{Cu}$ & 2,000 & 0.4 & 0.3 \\
\hline $\mathrm{Cr}$ & 50 & 0.04 & 0.001 \\
\hline $\mathrm{Fe}$ & 2,450 & 9 & 20 \\
\hline $\mathrm{Mn}$ & 400 & 259 & 91 \\
\hline $\mathrm{Hg}$ & 1 & - & - \\
\hline Mo & 70 & - & - \\
\hline $\mathrm{Ni}$ & 20 & 0.06 & 0.7 \\
\hline $\mathrm{NO}_{3}^{-}$ & 10,000 & 7,672 & 8,195 \\
\hline $\mathrm{Ag}$ & 50 & 0.1 & 0.05 \\
\hline $\mathrm{Se}$ & 10 & 0.6 & 0.6 \\
\hline $\mathrm{V}$ & - & 0 & 0 \\
\hline $\mathrm{Zn}$ & 1,050 & 13 & 72 \\
\hline${ }^{* *} \mathrm{PO}_{4}^{3-}$ & - & 176 & 19 \\
\hline
\end{tabular}

${ }^{*}$ According to CONAMA Resolution n 420/2009. ${ }^{* *}$ Trophic State Classification according to Carlson's Index (Cetesb, 2007).

in relation to cadmium, has been observed in other studies (Appel et al., 2008). However, in this study both were little movable with the total zinc and cadmium leached in $1250 \mathrm{~mm}$, ranging from 0.5 to $3 \%$ of the total added to the zinc and from 0 to $0.3 \%$ for cadmium (Table 2). However, the buffer effect of the soil may have acted softening these results, so a batch of biosolids containing higher content of these elements could lead to different results.

Several soil properties affect the pathway and, consequently, the availability and mobility of metals. According to Campos (2010), the behavior of heavy metals in soil $\mathrm{pH}$ depends on the quantity and nature of the soil organic matter (SOM), the redox potential, the typology and amount of clay and cation exchange capacity (CEC).

Thus, it is possible to speculate that the low mobility of metals found in this study may be related to the high content of organic matter and CEC of the own biosolids. A low leaching of metals can also be related to the interaction of factors such as elevation of soil $\mathrm{pH}$, presence of organic binders and calcium due to the application of biosolids and $\mathrm{Fe}$ and $\mathrm{Al}$ oxides in the soils.

The ability of interaction of SOM with metallic cations in the soil can be due to the high concentration of functional groups on the surface of organic components, which provide sites for the sorption of cations. The occurrence of these functional groupings, such as the carboxylic, phenolic, alcoholics, enolic, carbonyls and sulfhydryl groups, confer the SOM high reactivity with the metallic cations, resulting in the formation of complexes and chelates of different stability and structural characteristics (Sposito et al., 1996). Several compounds of organic matter may affect the availability of metals, however, humic substances exert the greatest contribution in the metal's complexation. 
Therefore, it is understood that the organic matter added by the biosolids ends up promoting greater metals immobilization, thus reducing the levels of these in the leached substances of the soil. Reeves (1997) states that despite of being a source of metals, the sludge can also be considered as immobilizing agent of metals. Its high organic load acts as a heavy metal's controller due to the complexation and chelation reactions, reducing its mobility and availability. However, to the extent that the decomposition of organic matter occurs, it is likely that there is a sudden increase of contents available of some heavy metals, while promoting the reduction of $\mathrm{pH}$ and cation exchange capacity (McBride, 1995).

Thus, a thorough study regarding the association of metallic cations with the humic fractions present in organic matter can assist in understanding the mechanisms involved in the reduction or increase of the availability of metals during the humification process.

\subsection{Leaching of nitrate and phosphate anions}

\subsubsection{Nitrate}

Despite the result is below the limits established by CONAMA Resolution n ${ }^{\circ} 420 / 2009$, a new application of biosolids could exceed the allowable limit making the environment contaminated (Table 3). However, the depth of the column may have influenced these results, and it may be assumed that in a deeper soil profile these values of leachate may be reduced.

Andrade et al. (2009) pointed out that the nitrate ion has a higher rate of leaching, due to not being adsorbed by components of the soil fraction, only by the roots of the plants, or even percolating to groundwaters.

According to Primavesi et al. (2006), when $\mathrm{NO}_{3}$ in the soil solution is not absorbed by plants or immobilized by soil microbiota, it can easily be leached, because it has a negative charge and is not adsorbed by soil colloids that have predominantly negative charges.

The absence of plant species in the leaching column may have contributed to the large amount of nitrate leachate, since this after being mineralized was not absorbed, remaining free and liable to be leached.

According to Boeira \& Maximiliano (2009), successive applications of sewage sludge can generate a cumulative process of organic nitrogen in the soil, increasing even more the risk of nitrate leaching.

In its technical manual for agricultural use of sewage sludge, the Sanitation Company of Paraná highlights nitrogen as possible limiting factor to the maximum dosage of sludge to be applied to the soil, due to the possibility of nitrate leaching, causing water table contamination (SANEPAR, 1997).

\subsubsection{Phosphate}

The eutrophication risk assessment of surface water was performed based on total phosphorus values indicated in the classification table of trophic state of rivers and reservoirs according to the Modified Carlson's Trophic State Index (CETESB, 2007).

Considering the application of $10 \mathrm{~m}^{3} / \mathrm{ha}$ of biosolids, a concentration of phosphate was estimated in percolated groundwater of 175.7 and $19.0 \mu \mathrm{g} / \mathrm{L}$ for Planosol and Latosol soil, respectively (Table 3 ). In case this percolated water reached a superficial body of water and was diluted in a proportion of 1:10, it would be possible to estimate the eutrophication risk based on the Trophic State Classification according to the Carlson's Index (CETESB, 2007). According to this assumption, the water from rivers or reservoirs that receive the percolated water in Planosol and Latosol would be classified as oligotrophic and ultraoligotrophic, respectively. Thus, according to this simulation there is no risk of surface waters contamination by phosphates leached of the biosolids, considering an application of $10 \mathrm{~m}^{3} / \mathrm{ha}$.

Kostyanovsky et al. (2011), comparing the incorporation in deep line of two types of biosolids digested anaerobically and stabilized with lime with inorganic fertilizers, concluded that the mobility of phosphorus present in the used biosolids should not pose a risk to water quality.

However, an experiment with greater duration could be planned, aiming at the consolidation of this statement. The high content of organic matter in the composition of sewage sludge may act by decreasing the phosphorus adsorption by soil mineral colloids due to the provision of organic ions that compete with the phosphate adsorption sites (Caldeira et al., 2009), decreasing the element fixation in the soil or substrate.

\section{CONCLUSIONS}

The biosolids of ETE Ilha do Governador complies with the quality requirements regarding heavy metals, showing no danger of soil and groundwater contamination 
and, therefore, susceptible to its use for agricultural and forestry purposes.

The largest part of metals content added to soil through biosolids application was not leached, regardless of the type of soil, probably due to the high content of organic matter of biosolids.

The nitrate leaching, despite being below the limits required by legislation, may confer potential risk of groundwater contamination if doses above $10 \mathrm{~m}^{3} /$ ha are applied to the soil. On the other hand, there is no risk of surface waters contamination by leachate phosphates of biosolids.

\section{ACKNOWLEDGEMENTS}

We thank CAPES for its financial support, and the Nova Cedae for its support to the LAPER (Laboratory of Research and Studies in Reforestation) study group and for encouraging research.

\section{SUBMISSION STATUS}

Received: 16 nov., 2018

Accepted: 4 dec., 2018

\section{CORRESPONDENCE TO}

\section{Thaís Campos}

Universidade Federal Rural do Rio de Janeiro UFRRJ, BR-465, Km 7, CEP 23897000, Seropédica, RJ, Brasil

e-mail: thaiscampospbi@gmail.com;

thaiscampos@ufrri.br

\section{FINANCIAL SUPPORT}

This study was financed in part by the Coordenação de Aperfeiçoamento de Pessoal de Nível Superior - Brasil (CAPES) - Finance Code 001. Nova Cedae - Companhia Estadual de Águas e Esgotos do Rio de Janeiro.

\section{REFERENCES}

Abreu AHM, Leles PSS, Melo LA, Oliveira RR, Ferreira DHAA. Caracterização e potencial de substratos formulados com biossólido na produção de mudas de Schinus terebinthifolius Raddi. e Handroanthus heptaphyllus
(Vell.) Mattos. Ciência Florestal 2017; 27(4): 1179-1190. http://dx.doi.org/10.5902/1980509830300.

Andrade EM, Aquino DN, Crisóstomo LA, Rodrigues JO, Lopes FB. Impacto da lixiviação de nitrato e cloreto no lençol freático sob condições de cultivo irrigado. Ciência Rural 2009; 39(1): 88-95. http://dx.doi.org/10.1590/S010384782009000100014 .

Appel C, Ma LQ, Rhue RD, Reve W. Sequential sorption of lead and cadmium in three tropical soils. Environmental Pollution 2008; 155(1): 132-140. http://dx.doi.org/10.1016/j. envpol.2007.10.026. PMid:18069107.

Bertoncini EI, Mattiazzo ME. Lixiviação de metais pesados em solos tratados com lodo de esgoto. Revista Brasileira de Ciência do Solo 1999; 23(3): 737-744. http://dx.doi. org/10.1590/S0100-06831999000300029.

Boeira RC, Maximiliano VCB. Mineralização de compostos nitrogenados de lodos de esgoto na quinta aplicação em latossolo. Revista Brasileira de Ciência do Solo 2009; 33(3): 711-722. http://dx.doi.org/10.1590/ S0100-06832009000300023.

Cabreira GV, Leles PSS, Alonso JM, Abreu AHM, Lopes NF, Santos GR. Biossólido como componente de substrato para produção de mudas florestais. Floresta 2017; 47(2): 165-176. http://dx.doi.org/10.5380/rf.v47i2.44291.

Caldeira CF Jr, Souza RA, Santos AM, Sampaio RA, Martins ER. Características químicas do solo e crescimento de Astronium fraxinifolium Schott em área degradada adubada com lodo de esgoto e silicato de cálcio. Revista Ceres 2009; 56(2): 213-218.

Caldeira MVW, Delarmelina WM, Lübe SG, Gomes DR, Gonçalves EO, Alves AF. Biossólido na composição de substrato para a produção de mudas de Tectona grandis. Floresta 2012; 42(1): 77-84. http://dx.doi.org/10.5380/ rf.v42i1.26302.

Campos FS, Alves MC. Uso de lodo de esgoto na reestruturação de solo degradado. Revista Brasileira de Ciência do Solo 2008; 32(4): 1389-1397. http://dx.doi. org/10.1590/S0100-06832008000400003.

Campos MCC. Atributos dos solos e riscos de lixiviação de metais pesados em solos tropicais. Ambiência 2010; 6(3): 547-565.

Companhia de Saneamento do Paraná - SANEPAR. (1997). Manual técnico para utilização agrícola do lodo de esgoto no Paraná. Curitiba: SANEPAR.

Companhia de Tecnologia e Saneamento Ambiental CETESB. (2007). Relatório de qualidade das águas interiores no estado de São Paulo 2006. São Paulo: CETESB. (Série Relatórios da Secretaria de Estado do Meio Ambiente; vol. 1-2).

Conselho Nacional do Meio Ambiente - CONAMA. Resolução n. 375, de 29 de agosto de 2006. Diário Oficial da República Federativa do Brasil, Brasília (2006 ago. 29); Sec. 1: 141-146. 
Conselho Nacional do Meio Ambiente - CONAMA. Resolução n. 420, de 28 de dezembro de 2009. Diário Oficial da República Federativa do Brasil, Brasília (2009; dez. 28); Sec. 1: 81-84.

Gonçalves AC Jr, Schwantes D, Coelho GF, Nacke H, Strey L, Montovani PAB. Efeito da aplicação de biossólido na disponibilidade de nutrientes e metais pesados no milho. Revista de Estudos Ambientais 2012; 14(3): 77-87.

Kostyanovsky KI, Evanylo GK, Lasley KK, Daniels WL, Shang C. Leaching potential and forms of phosphorus in deep row applied biosolids underlying hybrid poplar. Ecological Engineering 2011; 37(11): 1765-1771. http:// dx.doi.org/10.1016/j.ecoleng.2011.07.008.

McBride MB. Toxic metal accumulation from agricultural use of sludge: are USEPA regulations protective? Journal of Environmental Quality 1995; 24(1): 5-18. http://dx.doi. org/10.2134/jeq1995.00472425002400010002x.

Merlino LCS, Melo WJ, Macedo FG, Guedes ACTP, Ribeiro MH, Melo VP et al. Bário, cádmio, cromo e chumbo em plantas de milho e em latossolo após onze aplicações anuais de lodo de esgoto. Revista Brasileira de Ciência do Solo 2010; 34(6): 2031-2039. http://dx.doi.org/10.1590/ S0100-06832010000600027.

Nobrega MAS, Pontes MS, Santiago EF. Incorporação do lodo de esgoto na composição de substrato para produção de mudas nativas. Acta Biomedica Brasiliensia 2017; 8(1): 43-55. http://dx.doi.org/10.18571/acbm.121.

Oliveira LFC, Lemke-de-Castro ML, Rodrigues C, Borges JD. Isotermas de sorção de metais pesados em solos do cerrado de Goiás. Revista Brasileira de Engenharia Agrícola e Ambiental 2010; 14(7): 776-782. http://dx.doi. org/10.1590/S1415-43662010000700014.

Paramashivam D, Dickinson NM, Clough TJ, Horswell J, Robinson BH. Potential environmental benefits from blending biosolids with other organic amendments before application to land. Journal of Environmental Quality 2017; 46(3): 481-489. http://dx.doi.org/10.2134/jeq2016.10.0421. PMid:28724106.

Passuello A, Cadiach O, Perez Y, Schuhmacher M. A spatial multicriteria decision making tool to define the best agricultural areas for sewage sludge amendment. Environment International 2012; 38(1): 1-9. http://dx.doi. org/10.1016/j.envint.2011.07.013. PMid:21982027.

Plachá I, Venglovský J, Maková Z, Martinéz J. The elimination of Salmonella typhimurium in sewage sludge by aerobic mesophilic stabilization and lime hydrated stabilization. Bioresource Technology 2008; 99(10): 42694274. http://dx.doi.org/10.1016/j.biortech.2007.08.056. PMid:17931859.

Prado AK, Cunha MET. Efeito da aplicação de lodo de esgoto e curtume nas características físico-químicas do solo e na absorção de nitrogênio por feijoeiro (Phaseolus vulgaris L.). UNOPAR Científica Ciências Exatas e Tecnológicas 2011; 10(1): 37-41.

Primavesi O, Primavesi AC, Corrêa LA, Silva AG, Cantarella H. Lixiviação de nitrato em pastagem de coastcross adubada com nitrogênio. Revista Brasileira de Zootecnia 2006; 35(3): 683-690. http://dx.doi.org/10.1590/ S1516-35982006000300008.

Reeves DW. The role of soil organic matter in maintaining soil quality in continuous cropping systems. Soil \& Tillage Research 1997; 43(1-2): 131-167. http://dx.doi.org/10.1016/ S0167-1987(97)00038-X.

Ricci AB, Padovani VCR, Paula Júnior DR. Uso de lodo de esgoto estabilizado em um solo decapitado. II - Atributos químicos e revegetação. Revista Brasileira de Ciência do Solo 2010; 34(2): 543-551. http://dx.doi.org/10.1590/ S0100-06832010000200028.

Sampaio TF, Guerrini IA, Backes C, Heliodoro JCA, Ronchi HS, Tanganelli KM et al. Lodo de esgoto na recuperação de áreas degradadas: efeito nas características físicas do solo. Revista Brasileira de Ciência do Solo 2012; 36(5): 1637-1645. http://dx.doi.org/10.1590/S0100-06832012000500028.

Sposito G, Martin-Neto L, Yang A. Atrazine complexation by soil humic acids. Journal of Environmental Quality 1996; 25(6): 1203-1209. http://dx.doi.org/10.2134/ jeq1996.00472425002500060005x. 